\title{
Benthic Bacteria Community Changes in Responses to Different Organic Resources from Macrophyte- and Algae-Dominated Areas of Lake Taihu, China
}

\author{
Yali Tang*, Dongmei Chen, Xiaoqin Yang, Ruohua Xu \\ Department of Ecology and Institute of Hydrobiology, Jinan University, Guangzhou, China \\ Email: *litangyali@163.com
}

How to cite this paper: Tang, Y.L., Chen, D.M., Yang, X.Q. and Xu, R.H. (2016) Benthic Bacteria Community Changes in Responses to Different Organic Resources from Macrophyte- and Algae-Dominated Areas of Lake Taihu, China. Advances in Microbiology, 6, 1040-1052.

http://dx.doi.org/10.4236/aim.2016.614097

Received: November 22, 2016

Accepted: December 16, 2016

Published: December 19, 2016

Copyright $\odot 2016$ by authors and Scientific Research Publishing Inc. This work is licensed under the Creative Commons Attribution International License (CC BY 4.0).

http://creativecommons.org/licenses/by/4.0/ (c) (i) Open Access

\begin{abstract}
Carbon resources play an important role in affecting the benthic bacterial community in shallow lakes. In this study, pyrosequencing was applied to compare bacteria phylogenic profile in incubated sediments with normal and exchanged organic detritus in macrophyte-dominated East Lake Taihu and algal-dominated Meiliang Bay. We observed significant bacteria species variations in sediments from two bays, regardless of treatments. RDA (Redundancy Analysis) analysis showed that sediment characteristics, especially concentrations of total nitrogen might account for this differentiation. Besides, algal-dominated Meiliang Bay sediment with addition of Vallisneria detritus exhibited higher bacterial species variations than the sediment amended with Microcystis detritus. To the contrary, sediments from macrophytedominated East Lake Taihu shared similar bacteria profile at all taxonomic levels and grouped together in MDS (multidimensional scaling) plots over the treatments with Vallisneria or Microcystis detritus addition into the sediment. We speculated that the different degradability of macrophyte detritus and algal detritus led to varied bacterial responses to exchanged organic resources and ultimately, the amounts, nutrient availability and degradability of organic resources may be main reasons for benthic bacteria community structure differentiation between the two states in shallow lakes.
\end{abstract}

\section{Keywords}

Macrophyte-Dominated Lake, Algal-Dominated Lake, Benthic Bacteria, Pyrosequencing, Organic Resources 


\section{Introduction}

Shallow lakes can have two alternative equilibria: a clear state dominated by aquatic vegetation, and a turbid state characterized by high algal biomass [1] [2]. These two aquatic ecosystems differ dramatically from the very beginning of the food web-producers as macrophyte or phytoplankton respectively [3] [4]. The producers support the lives including bacteria in water column, causing significant differences in bacterioplankton community composition between two ecological states [5] [6]. The detritus of dead phytoplankton and macrophyte would also sink into the sediment, and serve as important carbon resources supporting benthic bacteria growth [7] [8] [9] [10], accompanying with benthic bacteria community differentiation. Shao et al. [11] explored these benthic bacteria community structure varied both in the surface sediment and also across vertical gradients in two ecological states [12], using denaturing gradient gel electrophoresis (DGGE) in conjunction with sequence analysis (phylogenetic analysis). However, the low resolution of phylogenetic information revealed by DGGE cannot give a reasonable explanation. Pyrosequencing, using the detection of released pyrophosphate ( $\mathrm{PPi}$ ) during DNA synthesis, is an alternative technology for much more detailed characterization of nucleic acids than DGGE [13] [14].

Besides, Jones and Lennon developed a theoretical model demonstrating the microbial dormancy strategy. They reported that even if a huge range of microbial types are present, only few of them are adapted to local organic resource in most ecosystems, the remaining majority of species stay rare as dormant [15]. Those rare species generate a seed bank, which comprises individuals prepared to be resuscitated following environmental changes [16], in our case, the input of different organic resources. For the above information, we assume that the dominant benthic bacteria from these two alternative equilibria are acclimatized to their different local organic resources as mainly phytoplankton detritus and macrophyte detritus, and eventually result in benthic bacteria community composition differentiation. In that way, if we exchange their carbon resources, dramatically bacterial species variation with exchanged dominant species would be observed.

To testify this hypothesis, we sampled sediment cores from these two ecological ecosystems and incubated them with exchanged organic resources as Vallisneria sp. detritus and Microcystis sp. detritus, respectively. Pyrosequencing was carried out for the benthic bacteria inventory. Over $900016 \mathrm{~S}$ rRNA gene fragment sequences from each of four sediment samples were obtained. This lab experiment will help us understanding how functional benthic bacteria shift during Lake Regime shift from a clear state dominated by aquatic vegetation to a turbid state characterized by high algal biomass and give us hints for lake management.

\section{Experimental}

\subsection{Materials and Methods}

\subsubsection{Study Area}

Lake Taihu, as the third biggest lake in China, holds a surface area of $\sim 2338 \mathrm{~km}^{2}$ and an 
average depth of $1.9 \mathrm{~m}$. Besides, it exhibits spatial heterogeneity in physicochemical conditions and plankton community structure, with macrophyte- and alage-dominated zones separated by clearly defined boundaries, creating the right model for studying these two aquatic ecosystems. The lake is located in the Yangtze Delta in eastern China $\left(30^{\circ} 55^{\prime} \mathrm{N}-31^{\circ} 32^{\prime} \mathrm{N}, 119^{\circ} 52^{\prime} \mathrm{E}-126^{\circ} 36^{\prime} \mathrm{E}\right)$. The two sampling sites are located in East Lake Taihu ( $\left.31^{\circ} 10^{\prime} 02^{\prime \prime}, 120^{\circ} 22^{\prime} 57^{\prime \prime}\right)$ and Meiliang Bay (31 $\left.28^{\prime} 39^{\prime \prime}, 120^{\circ} 12^{\prime} 35^{\prime \prime}\right)$ in Wuxi. East Lake Taihu is a typical submerged macrophyte-dominated zone with high biomass of Vallisneria sp., while Meiliang Bay, located in the northern part of the lake, is characterized by high densities of Microcystis sp. and an absence of submerged macrophytes [17].

\subsubsection{Experimental Settings}

Six intact sediment cores (inner diameter $=15 \mathrm{~cm}$ ) including 3 form East Lake Taihu and the other 3 from Meiliang Bay were sampled at a depth of $20 \mathrm{~cm}$ and transported to the laboratory on August 22, 2012. The coreliners used for sampling consisted of transparent acrylic cylinders $(15 \times 33 \mathrm{~cm}$, inner diameter $\times$ height; sediment surface equivalent to $176.7 \mathrm{~cm}^{2}$ ) that were capped at both ends with rubber stoppers. After the acclimation and sediment stabilization period of $24 \mathrm{~h}$, each core from two different lake areas was taken out of the system and sampled to provide an initial state (regarded as EB and MB), others were used as incubation chambers. We added Microcystisdetritus to one sediment chamber from Meiliang Bay and Vallisneria detritus to one sediment chamber from East Lake Taihu as normal state and the control (regarded as Meiliang Bay sediment with Microcystisdetritus, MM and East Lake Taihu sediment with Vallisneriadetritus, EV respectively). The rest two chambers were added with exchanged detritus (Meiliang Bay sediment with Vallisneriadetritus, MV and East Lake Taihu sediment with Microcystis detritus, EM respectively). The biomass added was all $24.2 \mathrm{~g}$ to reflect the natural phytoplankton biomass deposition found in Lake Taihu and to be comparable. All the chambers were incubated at $28.5^{\circ} \mathrm{C}$ for 5 days. Both Vallisneria sp. and Microcystis sp. were collected from Lake Taihu in according sampling sites and prepared as detritus by freeze-drying and grinding.

\subsubsection{Analysis of Environmental Parameters}

After incubation, $\mathrm{pH}$ was measured immediately for surface sediments $(0-1 \mathrm{~cm})$.We also sampled the surface sediments $(0-1 \mathrm{~cm})$. The freeze-dried sediments were homogenised with a mortar and pestle and passed through a No. 10 sieve $(2 \mathrm{~mm}$ sieve mesh openings). Chlorophyll a ( $\mathrm{Chl}$ a) was extracted from freeze dried samples of approximately $1 \mathrm{~g}$ by leaching for $24 \mathrm{~h}$ in $90 \%$ acetone at $4^{\circ} \mathrm{C}$ in the dark. Chl a content was then analyzed using an ultraviolet spectrophotometer [18] [19]. Analysis of sediment total organic carbon concentrations (TOC), total nitrogen concentrations (TN) and total phosphorus concentrations (TP) were processed using an elemental analyzer (EA3000, EuroVector).

\subsubsection{DNA Extraction, $16 \mathrm{~S}$ rRNA Construction and Pyrosequencing}

The MoBioUltraClean Soil DNA isolation kit (MoBio Laboratories, USA) was used to 
extract total microbial community DNA from approximately $1 \mathrm{~g}$ of material per sample following the protocol of the manufacturer. DNA concentrations were qualified using NanoDrop spectrophotometer (NanoDrop Technologies Inc, DE). The V3-V5 region of the 16S rRNA gene (E. coli position 357 to 926) was targeted by barcoded primers for their high variability [20]. The sequences of the partial 16S rRNA genes were detected using a GS-FLX 454 sequencer (Roche). Fastaq files containing sequences were submitted to NCBI Sequence Read Achive (SRX 1283592).

\subsection{Sequences and Statistic Analysis}

Raw sequence reads were retrieved and subjected to the PyroNoise algorithm for removal of 454 sequencing errors [21]. Furthermore, primer sequences were trimmed and reads only between $200 \mathrm{bp}$ (not including primer sequences) to $1000 \mathrm{bp}$ were included. Sequences with chimeras were excluded using the UChime algorithm on the Mothur platform [22] [23]. Pairwise distances between aligned sequences were calculated. Sequences lower than $97 \%$ similarity (or 0.03 distance) were clustered into unique operational taxonomic units (OTUs) in Mothur. RDP Classifier was used to assign taxonomy [24]. Alpha diversity analysis like Shannon index and rarefaction curve was performed by QIIME [25]. Beta diversity was calculated based on Bray-Curtis similarity matrix [26], and the resulting matrix was used for multidimensional scaling (MDS) of the samples by PRIMER v5.0 software. To evaluate the influences of environmental variables on OTU variation in sediment samples, redundancy analyses (RDA) were performed using CANOCO 5.0 (SCIENTIA Software), for Detrended Correspondence Analysis (DCA) run on species variables indicated that the longest gradient was $<3$. Forward selections were performed for a selection of restrictive factors. The significance of the canonical axes together was assessed in permutation tests with 499 unrestricted Monte Carlo permutations.

\section{Results}

\subsection{Microbial Diversity}

A total of 45,438 effective reads was produced by pyrosequencing analysis of $16 \mathrm{~S}$ rRNA gene amplicons. 5270 operational taxonomic units (OTUs) at $97 \%$ sequence similarity were finally obtained. The rarefaction curves constructed on the basis of $16 \mathrm{~S}$ rRNA gene sequences nearly reached saturation level for the samples, suggesting that nearly entire microbial community was well covered (Figure 1).

The phylogenetic affiliation of microbes was assigned to 17 bacterial phyla, 3 candidate divisions at the phylum level (Figure 2) and distributed into 65 categories at class level, 182 categories at family level and 314 categories at genus level. All the sediments shared the same dominant species at phylum level as Proteobacteria $(33.0 \%-44.2 \%)$, Acidobacteria (8.5\% - 13.3\%), Actinobacteria (2.5\% - 10.1\%), Choloflexi (2.4\% - 5.1\%), Nistrospira $(0.9 \%-2.6 \%)$, Firmicutes $(0.8 \%-2.3 \%)$. Those are common phyla in lake sediments [27] [28]. Bar chart displaying the bacterial community composition of each sample at class level was also showed below (Figure 3). East Lake Taihu sediment 


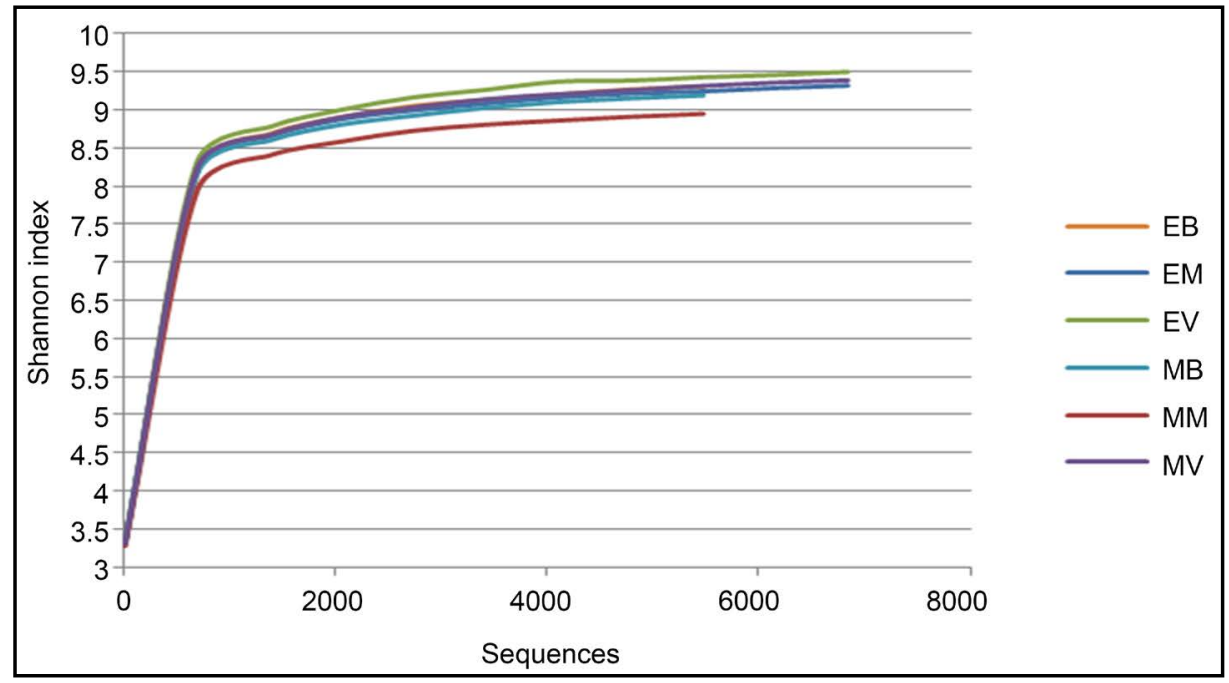

Figure 1. Diversity of microbial communities in sediment samples. EB represents non-incubated sediment sample from East lake Taihu. EV represents incubated sediment sample from East lake Taihu with Vallisneria detritus. EM represents sediment sample from the East lake Taihu incubated with Microcystis detritus. MB represents non-incubated sediment sample from Meiliang Bay. MM represents incubated sediment sample from Meiliang Bay with Microcystis detritus. MV represents sediment sample from Meiliang Bay incubated with Vallisneria detritus.

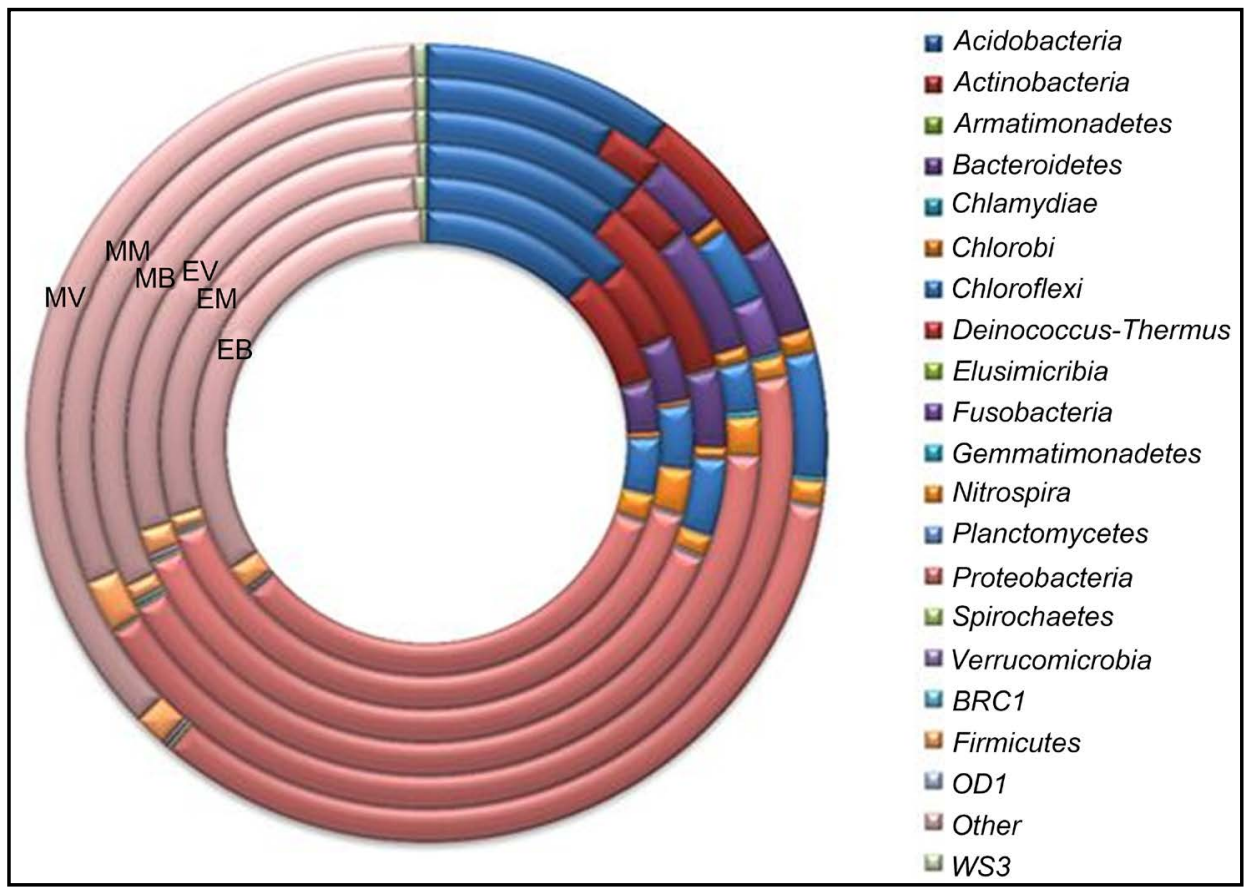

Figure 2. Visual representation of microbial distribution in samples at the phylum level, giving the 20 recognized taxa in all samples with unidentified taxa included as 'Other'. EB represents non-incubated sediment samples from East lake Taihu. EV represents incubated sediment sample from East lake Taihu with Vallisneria detritus. EM represents sediment sample from the East lake Taihu incubated with Microcystis detritus. MB represents non-incubated sediment from Meiliang Bay. MM represents incubated sediment from Meiliang Bay with Microcystis detritus. MV represents sediment from Meiliang Bay incubated with Vallisneria detritus. 


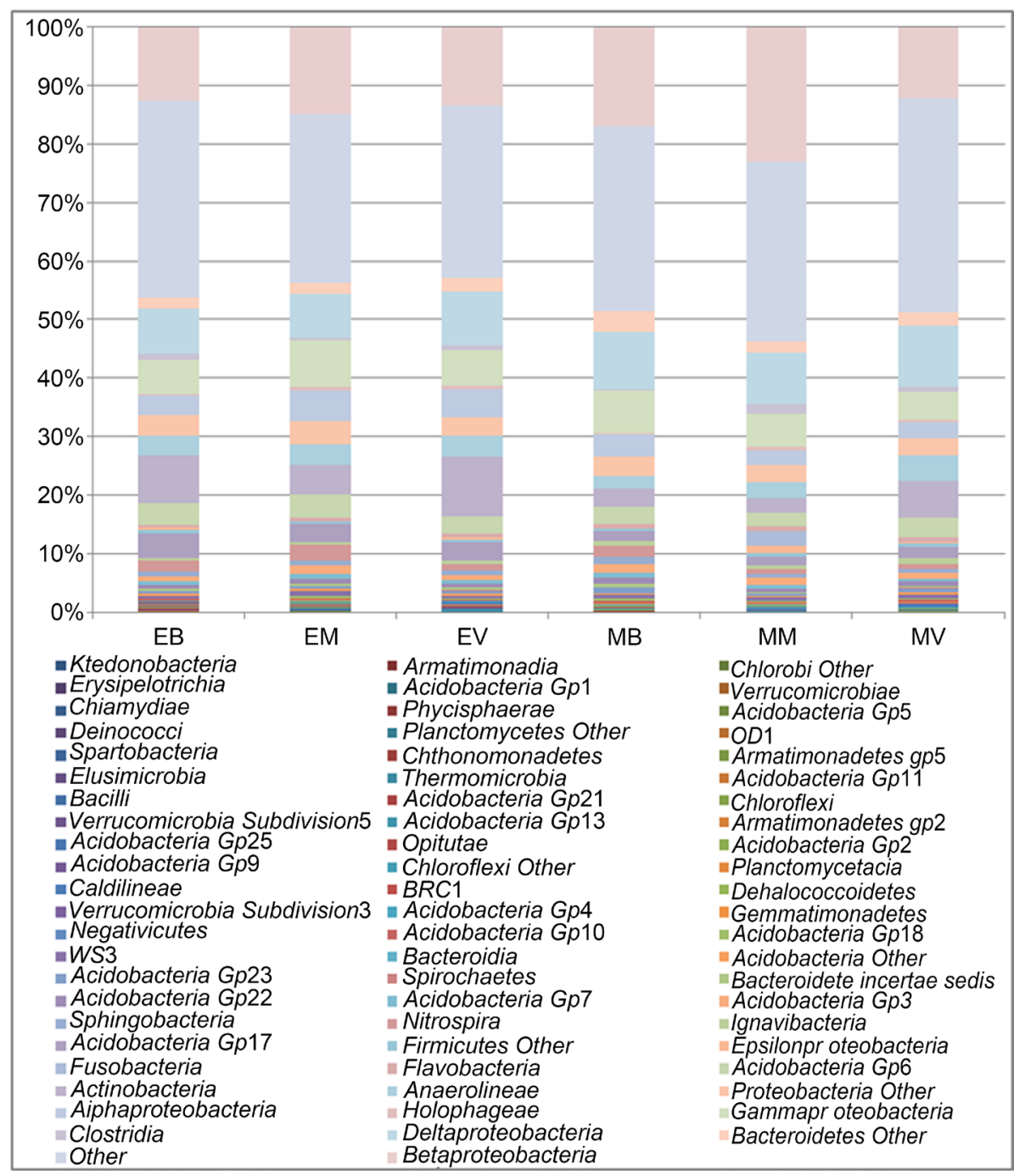

Figure 3. Bar chart displaying the bacterial community composition at class level. "Other" refers to unidentified class with no previous report of former taxa. EB represents non-incubated sediment sample from East lake Taihu. EV represents incubated sediment sample from East lake Taihu with Vallisneria detritus. EM represents sediment sample from the East lake Taihu incubated with Microcystis detritus. MB represents non-incubated sediment from Meiliang Bay. MM represents incubated sediment from Meiliang Bay with Microcystis detritus. MV represents sediment from Meiliang Bay incubated with Vallisneria detritus.

bacteria profiles with different treatments and with time showed similar patternat class level. However, bacteria constitution from Meiliang Bay incubated sediment with Vallisneria detritus showed distinct pattern with that from the other two Meiliang Bay originated sediments.

A hierarchical cluster tree and a multidimensional scaling (MDS) plot was drawn using PRIMER 5.0 (Figure 4). These two figures showed a visual representation of the similarity of sediments based on their bacterial community composition at the $97 \%$ OTU level. The hierarchical cluster tree showed that sediments from the different ecological state were separated to different clusters (Figure 4(a)). Meiliang Bay sediment 
sample incubated with Vallisneria sp. took another branch, apart from the other two Meiliang Bay sediment samples. In MDS plot (Figure 4(b)), we also noticed that all sediment samples from macrophyte-dominated East Lake Taihu were grouped together and dramatic species variations occurred among algae-dominated Meiliang Bay sediment samples incubated with exchanged organic resources.

\subsection{Redundancy Analysis}

We prepared a RDA biplot of the samples based on OUT level and 4 environmental variables $(\mathrm{TN}, \mathrm{TP}, \mathrm{Chla}, \mathrm{pH})$ to reveal the relationships between bacteria community changes and environmental parameters (Figure 5). We observed significant differences in environmental characteristics in sediments originated from the two ecological sites $(P<0.05)$. Sediments originated from algal-dominant area hold a higher average of TOC, TN, TP and Chla contents and a lower $\mathrm{pH}$ content than submerged macrophytedominated sediments.

In the graph, sediment samples from algae-dominated Meiliang Bay plotted on the right of axis 2, while Sediment samples from macorphyte-dominated Meiliang Bay plotted on the other side of axis 2. This RDA graph also demonstrated that TN played a significant role in the bacterial community variation in all sediments $(\mathrm{p}<0.05)$. The eigenvalues of the first and second axis were 0.3946 and 0.2334 , respectively, and these 2 axes explained $63.8 \%$ of the bacterial OTU variation in sediments. Permutation test on all axes showed that pseudo- $\mathrm{F}=1.8, \mathrm{p}=0.054$.

\subsection{OTU Variations}

At OTU level, $30 \%$ sequences was assigned to no more than $1 \%$ of the OTUs at $97 \%$ similarity levelin each sediment, other OTUs were found less than 20 sequences $(<0.37 \%)$. The large number of highly diverse, low-abundance OTUs constitutes a "rare biosphere" that might be inactive as a seed bank. SIMPER analysis was used to identify OTU variations in different sediment samples. OTUs contributed most to between-site

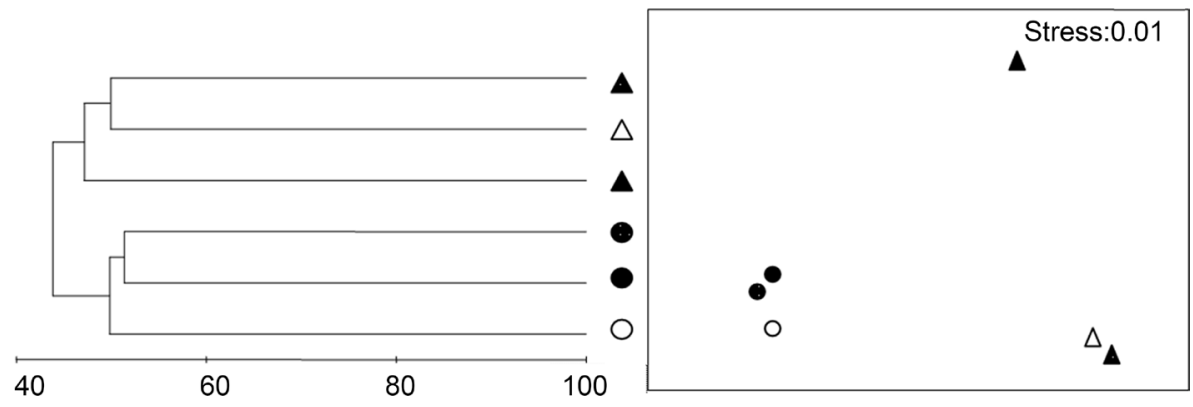

(a)

(b)

Figure 4. Visual representation of the similarity of sediments based on their bacterial community composition at the 97\% OTU level, including a. a MDS plot and b. a hierarchical cluster tree. Circles represent sediment samples from East lake Taihu. Triangles represent sediment samples from Meiliang Bay. Whites represent sediments without incubation. Blacks represent sediments incubated with Vallisneria detritus, and slashes represents incubated with Microcystis detritus. 


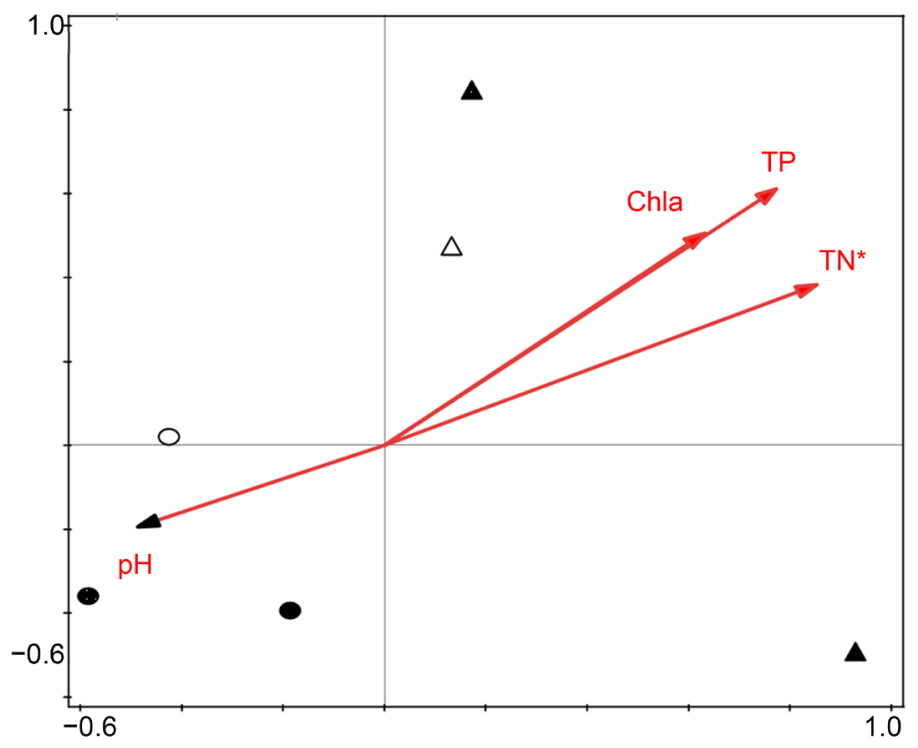

Figure 5. Redundancy analysis of biplots showed variable composition of bacteria in relation to the important environmental factors in different sediment samples. Circles represent sediment samples from East lake Taihu. Triangles represent sediment samples from Meiliang Bay. Whites represent sediments without incubation. Blacks represent sediments incubated with Vallisneria detritus, and slashes represents incubated with Microcystis detritus. Environmental variable marked with asterisks was significant $(\mathrm{p}<0.05)$.

differentiation and their population densities based on phylogenetic information in each sediment sample were showed in Table 1 . Similar species differentiations were observed in our incubated control sediment samples. Some of these OTUs stayed as top $1 \%$ OTUs in both two sediments at different ecological state, however in a distinct population density based on phylogenetic information. We also noticed that OTU00021 and OTU00019 stayed as rare species in Meiliang Bay sediment, and as dominant species in East Lake Taihu sediment. OTU00020 and OTU00024, to be opposite, stayed as rare species in East Lake Taihu sediment, and as dominant species in Meiliang Bay sediment.

OTUs contributed most to incubated Meiliang Bay sediments with Microcystis detritus and Vallisneria detritus and their population density in each sediment sample were showed in Table 2. OTU00005, OTU00004, OTU00001, OTU0008 and OTU00021, which had high contribution to between-site bacteria species differentiation, also contributed significantly to Meiliang Bay sediments added with varied organic resources. There are some OTUs stayed a relatively high population density in sediment from both sites and got an even higher population density in Meiliang Bay sediments with altered organic resources.

We didn't analyze the species variations between East Lake Taihu sediments with exchanged organic resourse for Bray-curtis dissimilarity calculated between them was less than the dissimilarity between the control and the background value.

\section{Discussion}

Our bacteria inventory by pyrosequencing demonstrated significant between-origin 
Table 1. SIMPER analysis results displaying 10 OTUs contributes most to bacterial community differentiation between macrophyte-dominant East lake Taihu and algal-dominant Meiliang Bay and their population density based on phylogenetic information in different sediment samples. EB represents non-incubated sediment sample from East lake Taihu. EV represents incubated sediment sample from East lake Taihu with Vallisneria detritus. MB represents non-incubated sediment from Meiliang Bay. MM represents incubated sediment from Meiliang Bay with Microcystis detritus.

\begin{tabular}{ccccccc}
\hline OTU & Assignation & EB (\%) & MB (\%) & Contribution (\%) & EV (\%) & MM (\%) \\
\hline OTU00001 & Acidobacteria Gp17 & 3.53 & 1.25 & 2.03 & 2.39 & 0.90 \\
OTU00005 & Unidentified Bacteria & 1.05 & 2.27 & 1.25 & 0.79 & 2.08 \\
OTU00021 & Actinobacteria & 1.50 & 0.19 & 1.20 & 1.52 & 0.24 \\
OTU00020 & Betaproteobacteria & 0.34 & 1.50 & 1.15 & 0.25 & 0.68 \\
OTU00004 & Desulfobacteraceae & 0.81 & 1.83 & 1.03 & 1.34 & 1.39 \\
OTU00008 & Proteobacteria & 1.79 & 0.70 & 0.96 & 1.30 & 0.76 \\
OTU00019 & Unidentified Bacteria & 1.14 & 0.22 & 0.83 & 1.27 & 0.46 \\
OTU00016 & Betaproteobacteria & 0.42 & 1.23 & 0.81 & 1.23 & 2.71 \\
OTU00024 & Betaproteobacteria & 0.36 & 1.09 & 0.73 & 0.18 & 0.47 \\
OTU00022 & Betaproteobacteria & 0.63 & 1.33 & 0.71 & 0.68 & 0.90 \\
\hline
\end{tabular}

Table 2. SIMPER analysis results displaying OTUs contributes most to bacterial community differentiation between algal-dominant Meiliang Bay sediment incubated with Vallisneria detritus and with Microcystis detritus and their population density based on phylogenetic information in different sediment samples. EB represents non-incubated sediment sample from East lake Taihu. EV represents incubated sediment sample from East lake Taihu with Vallisneria detritus. MB represents non-incubated sediment from Meiliang Bay. MM represents incubated sediment from Meiliang Bay with Microcystis detritus. MV represents sediment from Meiliang Bay incubated with Vallisneria detritus.

\begin{tabular}{|c|c|c|c|c|c|c|c|}
\hline OTU & Assignation & $\begin{array}{l}\text { MV } \\
(\%)\end{array}$ & $\begin{array}{l}\mathrm{MM} \\
(\%)\end{array}$ & $\begin{array}{c}\text { Contribution } \\
(\%)\end{array}$ & $\begin{array}{l}\text { MB } \\
(\%)\end{array}$ & $\begin{array}{l}\text { EB } \\
(\%)\end{array}$ & $\begin{array}{l}\text { EV } \\
\text { (\%) }\end{array}$ \\
\hline OTU00005 & $\begin{array}{c}\text { Unidentified } \\
\text { Bacteria }\end{array}$ & 2.92 & 2.08 & 1.40 & 1.25 & 3.53 & 2.39 \\
\hline OTU00004 & Desulfobacteraceae & 2.11 & 1.39 & 1.05 & 1.83 & 0.81 & 1.34 \\
\hline OTU00001 & $\begin{array}{c}\text { Acidobacteria } \\
\text { Gp17 }\end{array}$ & 1.56 & 0.90 & 0.86 & 1.25 & 3.53 & 185 \\
\hline OTU00014 & Acidobacteria Gp6 & 0.99 & 0.51 & 0.54 & 1.04 & 0.81 & 0.52 \\
\hline OTU00028 & Acidobacteria Gp6 & 1.02 & 0.59 & 0.53 & 0.79 & 0.65 & 0.28 \\
\hline OTU00078 & $\begin{array}{c}\text { Unidentified } \\
\text { Bacteria }\end{array}$ & 0.81 & 0.39 & 0.44 & 0.29 & 0 & 0.12 \\
\hline OTU00008 & Proteobacteria & 0.97 & 0.76 & 0.44 & 0.70 & 1.79 & 1.30 \\
\hline OTU00052 & $\begin{array}{c}\text { Unidentified } \\
\text { Bacteria }\end{array}$ & 0.77 & 0.39 & 0.42 & 0.56 & 0.43 & 0.56 \\
\hline OTU00011 & $\begin{array}{c}\text { Unidentified } \\
\text { Bacteria }\end{array}$ & 1.01 & 0.24 & 0.41 & 1.05 & 1.18 & 0.41 \\
\hline OTU00021 & Actinobacteria & 0.60 & 0.24 & 0.36 & 0.19 & 1.50 & 1.52 \\
\hline
\end{tabular}


species variations in algal-dominant Meiliang Bay originated sediments and macrophyte-dominant originated East Lake Taihu sediments, regardless of their different treatments. That result was possibly due to the different sediment characteristics between the two states. In the macrophyte-dominated state of East Lake Taihu, the organic fractions of the sediment mainly formed from the detritus of large vascular plants [11] [12]. In contrast, cyanobacteria detritus is also an important organic resource in sediment from algal-dominated lake area [29]. The higher primary production in cyanobacteria dominated areas of the lake increases the amount of organic resources. Besides, macrophytes were characterized as low $\mathrm{N}$ concentrations relatively to those of phytoplankton [30], which means their differences in nutrient availability. RDA analysis also showed that TN concentrations changes might have significantly impact on this between-origin differentiation.

There were no significant differences in sediment characteristics in incubated and non-incubated sediments, indicating that the nutrients we added into the sediments was much smaller compared to the intrinsic nutrients of sediments. All sediment samples from macrophyte-dominated East Lake Taihu also shared similar bacteria profile at all taxonomic levels and grouped together in MDS plots. However, in spite of similar sediment characteristics, the addition of Vallisneria detritus to algal-dominated Meiliang Bay sediment caused relatively large bacterial community changes comparing to the control and the background. Two main reasons may account for these different benthic bacteria responses. First is the different food quality of macrophyte and phytoplankton to bacteria. Comparing to labile phytoplankton, macrophyte was a less degradable resource for their complex tissue and high contents of lignin and fiber [31]. Certain bacteria are mores specialized at complex substrate decomposition with a more complex process, eg. The excretion of extracellular enzymes like cellulose [32] [33]. The addition of Vallisneria detritus to Meiliang Bay sediment made them more competitive, resulting in a elevated population density. Second, besides macrophyte-derived material, phytoplankton also contributed to sediment organic fraction in macrophyte dominated area [34] [35]. The identity and importance of the source materials that drive bacteria mineralization in sediments likely depends on a combination of their relative amounts and degradability [36]. In that case, phytoplankton detritus is also an accustomed small fraction of substrate for benthic bacteria in East Lake Taihu, and small amount of Microcystis detritus was regarded as normal condition. Therefore, we observed low bacteria community composition dissimilarity between non-incubated sediment, incubated sediment with Microcystis detritus and with Vallisneria detritus.

Detailed OTUs variations furtherly demonstrated how benthic bacteria in Meiliang Bay responses to Vallisneria detritus amendment. OTU00005, OTU00004 and OTU0008, which had high contribution to between-origin bacteria species, became higher in population density based on phylogenetic information with input of Vallisneria detritus, possibly for their better use of macrophyte derived organic resources. OTU00021, dominant in East Lake Taihu but rare in Meiliang Bay sediment, was triggered into activity with the amendment of Vallisneria detritus. Rest OTUs staying as top 1\% dominant 
bacteria in both Meiliang Bay and East Lake Taihu sediment might be able to decomposing both macrophyte detritus and phytoplankton detritus, while the addition of macrophyte detritus made them more competitive. We speculated that these OTUs were potentially specialized at macrophyte detritus degradation and their enhanced activity might responsible for the whole bacteria community composition changes with regard to macrophyte detritus addition in Meiliang Bay sediment.

\section{Conclusion}

In all, at least part of our hypothesis was true. The amounts, nutrient availability and the degradability of organic resources might have a profound effect on benthic bacteria community composition and ultimately caused benthic bacteria community differentiation in two ecological states.

\section{Acknowledgements}

This study was supported financially by National Natural Science Foundation of China (No. 31000219, No. 31570456 and No. 31370476) and Foundation of Guangdong Educational Committee (No. LYM10026).

\section{References}

[1] Scheffer, M., Hosper, S.H., Meijer, M.L., Moss, B. and Jeppesen, E. (1993) Alternative Equilibria in Shallow Lakes. Trends in Ecology \& Evolution, 8, 275-279. https://doi.org/10.1016/0169-5347(93)90254-M

[2] Scheffer, M., Carpenter, S., Foley, J.A., Folke, C. and Walker, B. (2001) Catastrophic Shifts in Ecosystems. Nature, 413, 591-596. https://doi.org/10.1038/35098000

[3] von Donk, E. and Gulati, R.D. (1995) Transition of a Lake to Turbid State Six Years after Biomanipulation: Mechanisms and Pathways. Water Science \& Technology, 32, 197-206. https://doi.org/10.1016/0273-1223(95)00699-0

[4] Chen, Y., Qin, B., Teubner, K. and Dokulil, M.T. (2003) Long-Term Dynamics of Phytoplankton Assemblages: Microcystis-Domination in Lake Taihu, a Large Shallow Lake in China. Journal of Plankton Research, 25, 445-453. https://doi.org/10.1093/plankt/25.4.445

[5] Llames, M.E., Paul, A.G., Zagarese, H., Ferraro, M. and Izaguirre, I. (2013) Alternative States Drive the Patterns in the Bacterioplankton Composition in Shallow Pampean Lakes (Argentina). Environmental Microbiology Reports, 5, 310-321. https://doi.org/10.1111/1758-2229.12020

[6] Wu, Q., Zwart, G., Wu, J., Agterveld, M., Liu, S. and Hahn, M.W. (2007) Submersed Macrophytes Play a Key Role in Structuring Bacterioplankton Community Composition in the Large, Shallow, Subtropical Taihu Lake, China. Environmental Microbiology, 9, 2765-2774. https://doi.org/10.1111/j.1462-2920.2007.01388.x

[7] Fallon, R.D. and Brock, T.D. (1980) Planktonic Blue-Green Algae: Production, Sedimentation, and Decomposition in Lake Mendota, Wisconsin. Limnology and Oceanography, 25, 72-88. https://doi.org/10.4319/lo.1980.25.1.0072

[8] Takamura, N. and Yasuno, M. (1988) Sedimentation of Phytoplankton Populations Dominated by Microcystis in a Shallow Lake. Journal of Plankton Research, 10, 283-299.

https://doi.org/10.1093/plankt/10.2.283 
[9] Mann, K.H. (1988) Production and Use of Detritus in Various Freshwater, Estuarine, and Coastal Marine Ecosystems. Limnology and Oceanography, 33, 910-930.

[10] Howarth, R.W. (1993) Microbial Processes in Salt-Marsh Sediments. In: Ford, T.E., Ed., Aquatic Microbiology: An Ecological Application. Blackwell, Massachusetts, 239-259.

[11] Shao, K., Gao, G., Qiang, B., et al. (2011) Comparing Sediment Bacterial Communities in the Macrophyte-Dominated and Algae-Dominated Areas of Eutrophic Lake Taihu, China. Canadian Journal of Microbiology, 57, 263-272. https://doi.org/10.1139/w11-003

[12] Shao, K., Gao, G., Wang, Y., Tang, X. and Qin, B. (2013) Vertical Diversity of Sediment Bacterial Communities in Two Different Trophic States of the Eutrophic Lake Taihu, China. Journal of Environmental Sciences, 25, 1186-1194. https://doi.org/10.1016/S1001-0742(12)60122-3

[13] Ronaghi, M. (2001) Pyrosequencing Sheds Light on DNA Sequencing. Genome Research, 11, 3-11. https://doi.org/10.1101/gr.11.1.3

[14] Hamady, M., Walker, J.J., Harris, J.K., Gold, N.J. and Knight, R. (2008) Error-Correcting Barcoded Primers for Pyrosequencing Hundreds of Samples in Multiplex. Nature Methods, 5, 235-237. https://doi.org/10.1038/nmeth.1184

[15] Jones, S.E. and Lennon, J.T. (2010) Dormancy Contributes to the Maintenance of Microbial Diversity. Proceedings of the National Academy of Sciences, 107, 5881-5886. https://doi.org/10.1073/pnas.0912765107

[16] Lennon, J.T. and Jones, S.E. (2013) Microbial Seed Banks: The Ecological and Evolutionary Implications of Dormancy. Nature Reviews, 9, 119-130.

[17] Qin, B.Q., Xu, P., Wu, Q., Luo, L. and Zhang, Y. (2007) Environmental Issues of Lake Taihu, China. Hydrobiologia, 581, 3-14. https://doi.org/10.1007/s10750-006-0521-5

[18] Black, K.D., Calder, L.A., Nickell, T.D., et al. (2012) Chlorophyll, Lipid Profiles and Bioturbation in Sediments around a Fish Cage Farm in the Gulf of Eilat, Israel. Aquaculture, 356-357, 317-327. https://doi.org/10.1016/j.aquaculture.2012.04.049

[19] Ritchie, R.J. (2006) Consistent Sets of Spectrophotometric Chlorophyll Equations for Acetone, Methanol and Ethanol Solvents. Photosynthesis Research, 89, 27-41. https://doi.org/10.1007/s11120-006-9065-9

[20] Adersson, A.F., Lindberg, M., Jakobsson, H., Bäckhed, F., Nyrén, P. and Engstrand, L. (2008) Comparative Analysis of Human Gut Microbiota by Barcoded Pyrosequencing. PLoS ONE, 3, e2836. https://doi.org/10.1371/journal.pone.0002836

[21] Quince, C., Lanzen, A., Davenport, R.J. and Turnbaugh, P.J. (2011) Removing Noise from Pyrosequenced Amplicons. BMC Bioinformatics, 12, 38. https://doi.org/10.1186/1471-2105-12-38

[22] Edgar, R., Haas, B.J., Clemente, J.C., Quince, C. and Knight, R. (2011) UCHIME Improves Sensitivity and Speed of Chimera Detection. Bioinformatics, 27, 2194-2200. https://doi.org/10.1093/bioinformatics/btr381

[23] Schloss, P.D., Westcott, S.L., Ryabin, T., et al. (2009) Introducing Mothur: Open-Source, Platform-Independent, Community-Supported Software for Describing and Comparing Microbial Communities. Applied and Environmental Microbiology, 75, 7537-7541. https://doi.org/10.1128/AEM.01541-09

[24] Cole, J., Wang, Q., Cardenas, E., et al. (2009) The Ribosomal Database Project: Improved Alignments and New Tools for rRNA Analysis. Nucleic Acids Research, 37, D141-D145. https://doi.org/10.1093/nar/gkn879

[25] Caporaso, J.G., Kuczynski, J., Stombaugh, J., et al. (2010) QIIME Allows Analysis of HighThroughput Community Sequencing Data. Nature Methods, 7, 335-336. 
https://doi.org/10.1038/nmeth.f.303

[26] Bray, J.R. and Curtis, J.T. (1957) An Ordination of the Upland Forest Communities of Southern Wisconsin. Ecological Monographs, 27, 325-349. https://doi.org/10.2307/1942268

[27] Spring, S., Schulze, R., Overmann, J. and Schleifer, K.-H. (2000) Identification and Characterization of Ecologically Significant Prokaryotes in the Sediment of Freshwater Lakes: Molecular and Cultivation Studies. FEMS Microbiology Reviews, 24, 573-590. https://doi.org/10.1111/j.1574-6976.2000.tb00559.x

[28] Bai, Y.H., Shi, Q., Wen, D.H., et al. (2012) Bacterial Communities in the Sediments of Dianchi Lake a Partitioned Eutrophic Waterbody in China. PLoS ONE, 7, e37796. https://doi.org/10.1371/journal.pone.0037796

[29] Yu, J., Li, Y., Liu, X., et al. (2013) The Fate of Cyanobacterial Detritus in Food Web of Lake Taihu: A Mesocosm Study Using ${ }^{13} \mathrm{C}$ and ${ }^{15} \mathrm{~N}$ Labeling. Hydrobiologia, 710, 39-46. https://doi.org/10.1007/s10750-012-1205-y

[30] Duarte, C.M. (1992) Nutrient Concentration of Aquatic Plants: Patterns Cross Species. Limnology and Oceanography, 37, 882-889. https://doi.org/10.4319/1o.1992.37.4.0882

[31] Ye, L., Wu, X., Tan, X., et al. (2010) Cell Lysis of Cyanobacteria and Its Implications for Nutrient Dynamics. International Review of Hydrobiology, 95, 235-245. https://doi.org/10.1002/iroh.200911194

[32] Wicks, R.J., Moran, M.A., Pittman, L.J. and Hodson, R.E. (1991) Carbohydrate Signatures of Aquatic Macrophytes and Their Dissolved Degradation Products as Determined by a Sensitive High-Performance Ion Chromatography Method. Applied and Environmental Microbiology, 57, 3135-3143.

[33] Cunha, A., Almeida, A., Coelho, F.J.R.C., Gomes, N.C.M., Oliveira, V. and Santos, A.L. (2010) Bacterial Extracellular Enzymatic Activity in Globally Changing Aquatic Ecosystems. In: Mendez-Vilas, A., Ed., Current Research, Technology and Education Topics in Applied Microbiology and Microbial Biotechnology, Formatex Research Center, Badajoz, 124-135.

[34] Middelburg, J.J., Nieuwenhuize, J., Lubberts, R.K. and Plassche, O.V.D. (1997) Organic Carbon Isotope Systematics of Coastal Marshes. Estuarine, Coastal and Shelf Science, 45, 681-687. https://doi.org/10.1006/ecss.1997.0247

[35] Boschker, H.T.S., de Brouwer, J.F.C. and Cappenberg, T.E. (1999) The Contribution of Macrophyte-Derived Organic Matter to Microbial Biomass in Salt-Marsh Sediments: Stable Carbon Isotope Analysis of Microbial Biomarkers. Limnology and Oceanography, 44, 309319. https://doi.org/10.4319/1o.1999.44.2.0309

[36] Bouillon, S. and Boschker, H.T.S. (2006) Bacterial Carbon Sources in Coastal Sediments: A Cross-System Analysis Based on Stable Isotope Data of Biomarkers. Biogeosciences, 3, 175185. https://doi.org/10.5194/bg-3-175-2006 
Submit or recommend next manuscript to SCIRP and we will provide best service for you:

Accepting pre-submission inquiries through Email, Facebook, LinkedIn, Twitter, etc. A wide selection of journals (inclusive of 9 subjects, more than 200 journals)

Providing 24-hour high-quality service

User-friendly online submission system

Fair and swift peer-review system

Efficient typesetting and proofreading procedure

Display of the result of downloads and visits, as well as the number of cited articles

Maximum dissemination of your research work

Submit your manuscript at: http://papersubmission.scirp.org/

Or contact aim@scirp.org 